\title{
Leaf Extracts of Calocedrus formosana (Florin) Induce G2/M Cell Cycle Arrest and Apoptosis in Human Bladder Cancer Cells
}

\author{
Sheau-Yun Yuan, ${ }^{1,2}$ Chi-Chen Lin,, ${ }^{3,4}$ Shih-Lan Hsu, ${ }^{3}$ Ya-Wen Cheng, ${ }^{1}$ \\ Jyh-Horng Wu, ${ }^{5}$ Chen-Li Cheng, ${ }^{2}$ and Chi-Rei Yang ${ }^{2}$ \\ ${ }^{1}$ Institute of Medicine, Chung Shan Medical University, Taichung 40201, Taiwan \\ ${ }^{2}$ Division of Urology, Department of Surgery, Taichung Veterans General Hospital, Taichung 40705, Taiwan \\ ${ }^{3}$ Department of Education and Research, Taichung Veterans General Hospital, Taichung 40705, Taiwan \\ ${ }^{4}$ Institute of Biomedical Science, National Chung-Hsing University, Taichung 40227, Taiwan \\ ${ }^{5}$ Department of Forestry, National Chung-Hsing University, Taichung 40227, Taiwan \\ Correspondence should be addressed to \\ Chen-Li Cheng, cheng20011@gmail.com and Chi-Rei Yang, cryang@vghtc.gov.tw
}

Received 14 December 2010; Revised 14 March 2011; Accepted 24 March 2011

Copyright (C) 2011 Sheau-Yun Yuan et al. This is an open access article distributed under the Creative Commons Attribution License, which permits unrestricted use, distribution, and reproduction in any medium, provided the original work is properly cited.

Calocedrus formosana (Florin) bark acetone/ethylacetate extracts are known to exert an antitumor effect on some human cancer cell lines, but the mechanism is yet to be defined. The aim of this study was to determine the effects of Florin leaf methanol extracts on the growth and apoptosis of human bladder cancer cell lines. MTT (3-(4,5-Dimethylthiazol-2-yl)-2,5-diphenyltetrazolium bromide) assay showed that the growth of these bladder cancer cells was potently inhibited by the Florin leaf extracts. The cell cycle of these extract-treated cells (TCCSUP cells) was arrested at the G2/M phase as determined by flow cytometry. Western blot analysis revealed the increases of cyclin B1 and Cdc2 kinase levels, alone with the decrease of phosphorylated Cdc2 kinase, after treating these cells with the extracts. An immunofluorescence assessment of $\beta$-tubulin showed decreased levels of polymerized tubulin in treated cells. However, the proteolytic cleavage of poly ADP-ribose polymerase and the activation of caspase-3/-8/-9 were all increased upon treatments of extracts. The concurrent increase of Bax and decrease of Bcl-2 levels indicated that the extracts could induce apoptosis in these treated cells. Taken together, these results suggest that the Florin leaf extracts may be an effective antibladder cancer agent.

\section{Introduction}

According to a recent study, urinary bladder cancer including transitional cell carcinoma (TCC) affects more than 2 million people worldwide [1]. Bladder cancer has been ranked as the seventh most common type of cancer in Taiwanese males and is still rising in incidence and prevalence [2]. Usually, bladder cancers are grouped into two types of clinical manifestation, depending on the pathological stage: low-grade (G1, G2)/noninvasive cancers (pTa, pT1) and high-grade (G3)/muscle invasive lesions (greater than pT2) [3]. Intermediate to high-grade or metastatic TCC is more difficult to treat and is lethal in $\sim 50 \%$ of patients [1].

Recently, many natural products have served as pharmaceutical resources in treating and preventing human diseases throughout the world $[4,5]$. For example, over
$60 \%$ of prevalent anticancer drugs, including vinblastine, topotecan, etoposide, and paclitaxel, were originally plantderived compounds $[6,7]$. Calocedrus formosana (Florin) belongs to the Cupressaceae family and grows at an altitude of $800-1500$ meters in the north central mountain region of Taiwan [8]. Extracts from the bark of Florin have been suggested to possess some bio-active effects, such as antioxidative [9], anti-inflammatory [10], immunoregulatory [11], antitermitic, and antifungal activities $[8,12]$. It has also been proposed to have antitumoral properties [13]. Most studies have focused on the Florin bark as a medical source, but few studies have investigated the use of the Florin leaf as an anticancer pharmaceutical resource. In this study, we investigated the effect of Florin leaf methanol extracts on the growth of human bladder carcinoma cells, including TCCSUP cells that are derived from a high-grade 
and invasive human urinary bladder tumor [14]. Here we demonstrate that the Florin leaf methanol extracts inhibit growth of these bladder carcinoma cells by arresting cell cycle at the G2/M phase and inducing apoptosis.

\section{Materials and Methods}

2.1. Preparation of Florin Extracts. The Florin leaves were collected from the Hui-Sun Forest Station of National Chung Hsing University in Taichung, Taiwan. Leaves were washed, air-dried, and extracted twice with methanol by ultrasonication for $30 \mathrm{~min}$ at room temperature. The extracts were then filtered, concentrated, and then lyophilized. Florin extracts was prepared by dissolving the lyophilized powder in dimethylsulfoxide to a final concentration of $50 \mathrm{mg} / \mathrm{mL}$. The stock was stored at $-20^{\circ} \mathrm{C}$ until use.

2.2. Cell Culture. Human bladder cancer cell lines (TCCSUP, T24, TSGH-8301, and RT4 cells) and SV-40-immortalized normal uroepithelial cells (SV-HUC-1 cells) were purchased from the Food Industry Research and Development Institute (FIRDI) (Hsinchu, Taiwan). TCCSUP cell line (Grade IV, mutant p53) was isolated from an anaplastic transitional cell carcinoma (TCC) [14]; T24 cells were derived from an invasive bladder tumor of grade III, having p53 nonsense mutation at codon 126 (TAC to TAG); TSGH-8301 cells (grade II), having wt $p 53$ but mutant $R b$ gene, were derived from a well-differentiated human TCC; RT4 cells (grade I) were established from a well-differentiated papillary tumor of the bladder and have the wt $p 53$ and $R b$ gene [15]. Cell lines were cultured in McCoy's 5A and RPMI medium supplemented with $10 \%$ fetal bovine serum (FBS) (Gibco, Gaithersburg, MD), L-glutamine (200 mM), and penicillin/streptomycin/amphotericin B (10,000 IU/mL, $10,000 \mu \mathrm{g} / \mathrm{mL}$, and $25 \mu \mathrm{g} / \mathrm{mL}$ ) solution. Cells were incubated at $37^{\circ} \mathrm{C}$ with $5 \% \mathrm{CO}_{2}$.

2.3. Cell Survival Assay. Bladder cancer cells and normal uroepithelial cells $\left(1 \times 10^{4}\right)$ were plated onto 24 -well plates and treated with Florin extracts at concentrations of 3, $6,12,25$, and $50 \mu \mathrm{g} / \mathrm{mL}$ or vehicle alone for $48 \mathrm{~h}$. MTT (3-(4,5-Dimethylthiazol-2-yl)-2,5-diphenyltetrazolium bromide) solution $(200 \mu \mathrm{L}$ from $1 \mathrm{mg} / \mathrm{mL})$ was added to each well, and the plates were further incubated at $37^{\circ} \mathrm{C}$ for $4 \mathrm{~h}$. The medium was aspirated and the formazan product in cells was solubilized by adding DMSO. An aliquot of $150 \mu \mathrm{L}$ was measured by a Microplate Autoreader (Tecan Deutschland $\mathrm{GmbH}$, Crailsheim, Germany) at wavelength of $570 \mathrm{~nm}$. The experiments were carried out in triplicate.

2.4. Apoptosis Assay-Annexin V Apoptosis and DAPI Staining. Florin-extract treated TCCSUP cells were stained by FITCconjugated Annexin-V and propidium iodide (PI) using an Annexin V-FITC Apoptosis Detection kit (BioVision, CA, USA) and analyzed by a Becton-Dickinson FACSCalibur with CellQuest software (BD Biosciences, San Diego, CA, USA). After 24 h of treatment, the cells were washed with PBS and fixed in 2\% paraformaldehyde for $30 \mathrm{~min}$, and then permeabilized with $0.1 \%$ Triton-X 100 in PBS for $30 \mathrm{~min}$. Nuclei were stained by incubating the cells with DAPI $(1 \mu \mathrm{g} / \mathrm{mL})$ and examined under a fluorescence microscope. Five randomlychosen fields of view per well were inspected and the number of intact nuclei and the number of multinuclear cells were counted.

2.5. Cell Cycle Distribution by Flow Cytometry Analysis. The treated cells were collected after trypsinization and washed with ice-cold PBS, fixed and permeabilized with 70\% ethanol at $-20^{\circ} \mathrm{C}$ overnight. On the next day, after cells were washed with ice-cold PBS, they were incubated with PI $(20 \mu \mathrm{g} / \mathrm{mL})$ and RNase $(100 \mu \mathrm{g} / \mathrm{mL})$ for $30 \mathrm{~min}$ at room temperature in the dark. Data were collected from the flow cytometer and analyzed with the accompanying software (CellQuest; BD Biosciences, San Diego, CA, USA). Ten thousand events per sample were counted and the experiments were performed in triplicate. Data represent the means \pm standard deviations of 3 independent experiments.

2.6. Western Blot Analysis. Cell lysates with equal amounts of proteins, which were measured using a BCA Protein Reagent Kit (Pierce, Rockford, IL, USA), were analyzed by Western blot, using a rabbit polyclonal antibody to cdc2 phosphorylated at Tyr15 (p-Cdc2) (1:1000; R\&D, Minneapolis, MN, USA), a rabbit polyclonal cdc2 antibody (1:1000; Cell Signaling Technology, St. Louis, MO, USA), a mouse monoclonal antibody to cyclin B1 (sc-254; $1: 200)$ (Santa Cruz Biotechnology, Santa Cruz, CA, USA), a mouse monoclonal antibody to poly (ADP-ribose) polymerase (PARP) $(0.5 \mu \mathrm{g} / \mathrm{mL}$; from BD Biosciences, Franklin Lakes, NJ, USA), a mouse monoclonal antibody to $\mathrm{Bcl}-2$, a rabbit polyclonal antibody to Bax (1:200; both from DAKO, Taipei, Taiwan), an anti- $\beta$-tubulin mouse monoclonal antibody ( $1: 20000$; Epitomics, Burlingame, California), or a mouse monoclonal antibody against human GAPDH ( $1: 1000$; Santa Cruz, CA, USA). Briefly, samples were run on $12 \%$ sodium dodecylsulfate (SDS)-polyacrylamide gels and electrophoretically transferred (SDS-PAGE) to nitrocellulose membranes (BioRad Laboratories, Hercules, CA). Nonspecific binding sites were blocked with 5\% skim milk powder diluted in PBS with $0.1 \%$ Tween 20 (SMP/PBST). Membranes were reacted with primary antibody followed by incubation with horseradish peroxidase-linked goat antirabbit or goat antimouse secondary antibodies (Santa Cruz, CA, USA) which were also diluted in PBST. Proteins were visualized by enhanced chemiluminescence (Amersham Biosciences, San Francisco, CA, USA). Each blot was stripped with Restore Western Blot Stripping Buffer (Millipore, Billerica, MA, USA) before being reprobed with other antibodies.

\subsection{Morphological Observation of Cells and Immunofluo-} rescence Confocal Microscopy for Tubulin. TCCSUP cells (1 $\times 10^{4}$ ) were treated by Florin extracts for $24 \mathrm{~h}$. The cell morphology was observed under a reverse microscope. For tubulin analysis, cells $\left(1 \times 10^{4}\right)$ were first seeded onto 2well chamber slides (Lab-Tek ${ }^{\mathrm{R}}$; Nunc, Roskilde, Denmark) 
and treated Florin extracts $(25 \mu \mathrm{g} / \mathrm{mL})$ for $24 \mathrm{~h}$. Cells were prefixed with $0.5 \%$ glutaraldehyde in $0.25 \%$ Triton X-100 in cytoskeleton buffer (CB) for $60 \mathrm{~s}$, washed twice ( $15 \mathrm{~min}$ each) with $\mathrm{CB}$, and refixed with $1 \%$ glutaraldehyde in $\mathrm{CB}$ for 10 min. The slides were blocked with $2 \%$ BSA in PBST $(0.1 \%$ Tween 20 in PBS) for $2 \mathrm{~h}$ and reacted with anti- $\beta$-tubulin rabbit monoclonal antibody (Abcam, Cambridge, MA, USA) at $4^{\circ} \mathrm{C}$ overnight. Slides were washed three times with PBST and incubated with Alexa 488-conjugated antirabbit IgG rabbit antibody (Invitrogen, Carlsbad, CA, USA) for $1 \mathrm{~h}$ at room temperature. Cells were counterstained with DAPI $(1 \mu \mathrm{g} / \mathrm{mL})$ and examined using a ZEISS LSM 510 confocal spectral microscope.

2.8. Analysis of Soluble and Polymerized $\beta$-Tubulin. The cells $\left(2 \times 10^{6}\right)$ were precultured for $24 \mathrm{~h}$ and treated with Florin extracts $(25 \mu \mathrm{g} / \mathrm{mL})$, colchicine $(0.05 \mu \mathrm{g} / \mathrm{mL})$, or Taxol $(0.1 \mu \mathrm{g} / \mathrm{mL})$ for $24 \mathrm{~h}$. After the cells were harvested with a scraper and washed with PBS, the cells were added to $100 \mu \mathrm{L}$ of microtubule-stabilizing buffer (MSB: $20 \mathrm{mM}$ Tris- $\mathrm{HCl}$, $1 \mathrm{mM} \mathrm{MgCl}_{2}, 2 \mathrm{mM} \mathrm{EGTA}$, and $0.5 \%$ Triton X-100) containing a proteinase inhibitor cocktail (Roche, Indianapolis, IN, USA). After incubation for $20 \mathrm{~min}$ at room temperature, the cell suspensions were centrifuged at $12,000 \times \mathrm{g}$ for $5 \mathrm{~min}$ at $25^{\circ} \mathrm{C}$. The supernatants (soluble fraction) were transferred to a new tube, while pellets were washed with MSB once and mixed with $50 \mu \mathrm{L}$ of protein lysis buffer (RIPA). After incubation at $4^{\circ} \mathrm{C}$ for $20 \mathrm{~min}$, the supernatants (polymerized fraction) were harvested by centrifugation at $100,000 \times \mathrm{g}$ for $30 \mathrm{~min}$ at $4^{\circ} \mathrm{C}$. Soluble and polymerized fractions were mixed separately with 4X NuPAGE LDS sample buffer (Invitrogen) and stored until analysis. Twenty micrograms of soluble and polymerized fractions were subjected to $10 \%$ SDSpolyacrylamide (SDS-PAGE) gel electrophoresis. The separated proteins on SDS-PAGE gel were electrically transferred to a PVDF membrane (Perkin Elmer, Boston, MA, USA) for immunoblot analysis. The membrane was incubated with anti- $\beta$-tubulin rabbit monoclonal antibody $(1: 20,000$; Abcam, Cambridge, USA) $4^{\circ} \mathrm{C}$ overnight and then incubated with horseradish peroxidase-labeled antirabbit secondary antibody $(1: 5000, \mathrm{R} \& \mathrm{D}$, Minneapolis, MN, USA) for $1 \mathrm{~h}$. The membrane was developed using the ECL plus Western blot detection system (Amersham Biosciences, San Francisco, CA, USA).

2.9. Determination of Caspase Activity. We used the colorimetric substrates Ac-DEVD-pNA, Ac-IETD-pNA, and AcLEHD-pNA (Biovision, California, USA) for caspase- $3,-8$, and -9 assays, respectively, according to the manufacturer's protocol. Briefly, aliquots of cell lysates were prepared in lysis buffer (50 mM HEPES, pH 7.4, $100 \mathrm{mM} \mathrm{NaCl}, 0.1 \%$ CHAPS, $1 \mathrm{mM}$ dithiothreitol, $0.1 \mathrm{mM}$ EDTA) and then incubated with $200 \mu \mathrm{M}$ of substrate in assay buffer (50 mM HEPES, pH 7.4, $100 \mathrm{mM} \mathrm{NaCl}, 0.1 \%$ CHAPS, $10 \mathrm{mM}$ dithiothreitol, $0.1 \mathrm{mM}$ EDTA, $10 \%$ glycerol) in 96 -well plates at $37^{\circ} \mathrm{C}$ for $2 \mathrm{~h}$. Absorbance of the cleaved product was measured at $405 \mathrm{~nm}$ in a TECAN Microplate Reader.

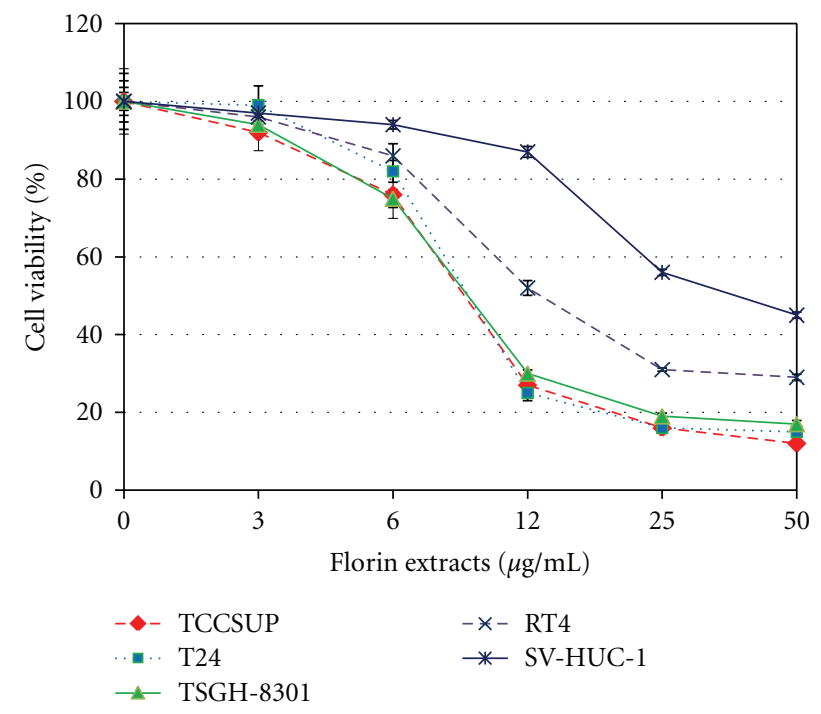

FIGURE 1: Effects of Florin extracts on cell viability of human bladder cancer cells (TCCSUP, T-24, TSGH-8301, and RT- 4 cells) and immortalized normal uroepithelial cells (SV-HUC-1 cells). These cells were treated with various concentrations $(3,6,12,25$, and $50 \mu \mathrm{g} / \mathrm{mL}$ ) of Florin extracts or vehicle only for $48 \mathrm{~h}$. Results are presented as mean \pm S.D. $(n=3)$.

2.10. Statistics. All data are presented as mean \pm S.D. The differences between the treated cells and the control cells were analyzed by Student's $t$-test. A $P$ value $<.05$ was considered statistically significant.

\section{Results}

3.1. Inhibition of Bladder Cancer Cell Growth by Different Dosages of Florin Extracts. Four bladder cancer cell lines (including TCCSUP, T24, TSGH-8301, and RT-4 cells) and immortalized normal uroepithelial cells (SV-HUC-1) were treated with various concentrations $(3-50 \mu \mathrm{g} / \mathrm{mL})$ of Florin extracts for $48 \mathrm{~h}$. The growth of these cells was determined by MTT assay. As shown in Figure 1, treatment with Florin extracts for $48 \mathrm{~h}$ inhibited growth of T-24, TCCSUP \& TSGH-8301 cells, and RT-4 cells in a concentrationdependent manner with $\mathrm{IC}_{50} \mathrm{~s}$ of $\sim 9-10$ and $\sim 17 \mu \mathrm{g} / \mathrm{mL}$, respectively. Treatment of SV-immortalized normal uroepithelial cells (SV-HUC-1 cells) with Florin extracts for $48 \mathrm{~h}$ also exhibited concentration-dependent growth inhibition but with a higher $\mathrm{IC}_{50}(\sim 27 \mu \mathrm{g} / \mathrm{mL})$. These results indicate that Florin extracts inhibit growth of malignant bladder cancer cells more effectively than normal uroepithelial cells.

\subsection{Apoptotic Effect of Florin Extracts on Bladder Cancer Cells.} TCCSUP cells were treated with $25 \mu \mathrm{g} / \mathrm{mL}$ of Florin extracts for 18 and $24 \mathrm{~h}$, and then stained with Annexin V-FITC and DAPI. With Annexin V-FITC staining, early apoptosis was clearly detectable in cells treated with $25 \mu \mathrm{g} / \mathrm{mL}$ of Florin extracts for $18 \mathrm{~h}(11.7 \%)$ (Figure 2(A)). The apoptotic nucleus-containing adherent and supernatant cells, which exhibited highly fluorescent condensed chromatin and cleaved nuclei, were observed in cells treated with $25 \mu \mathrm{g} / \mathrm{mL}$ 

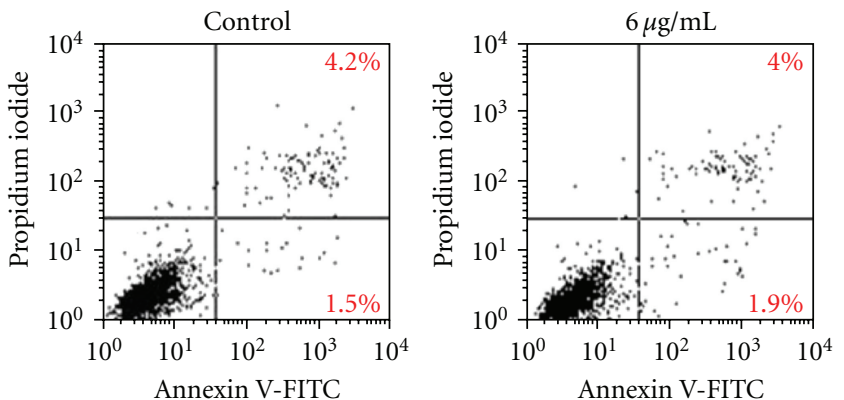

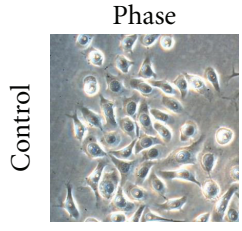

(a)

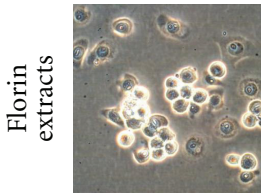

(d)

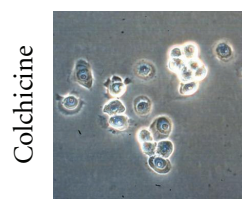

( g)

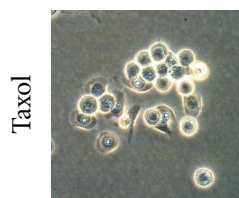

(j)

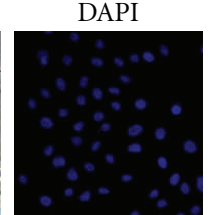

(b)

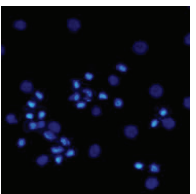

(e)

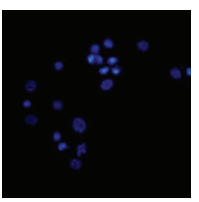

(h)

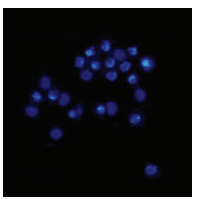

$(\mathrm{k})$

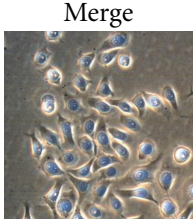

(c)

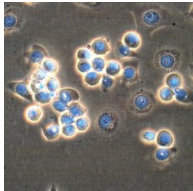

(f)

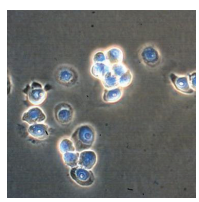

(i)

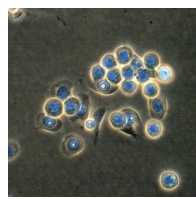

(1)

(A)

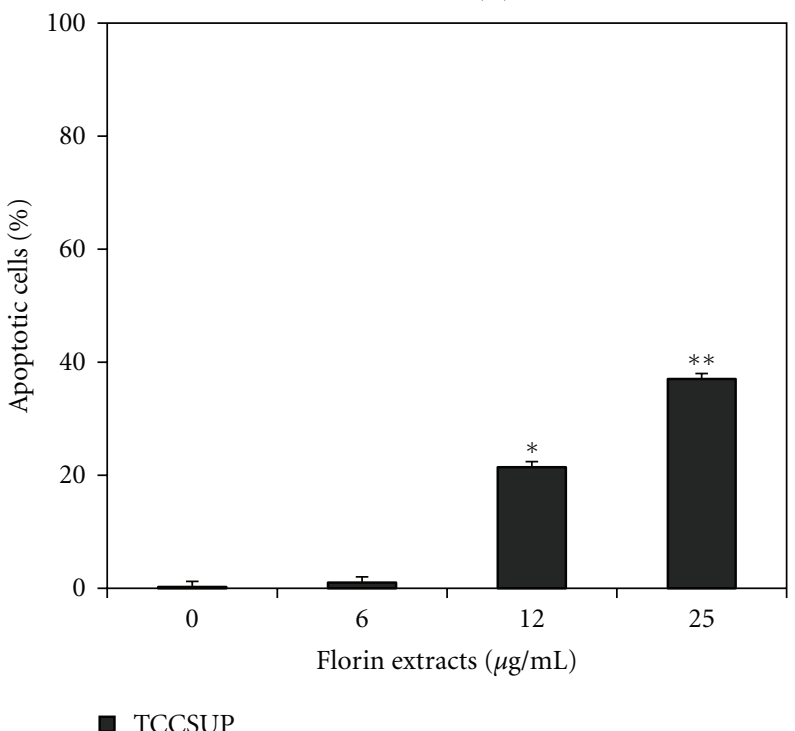

(C)

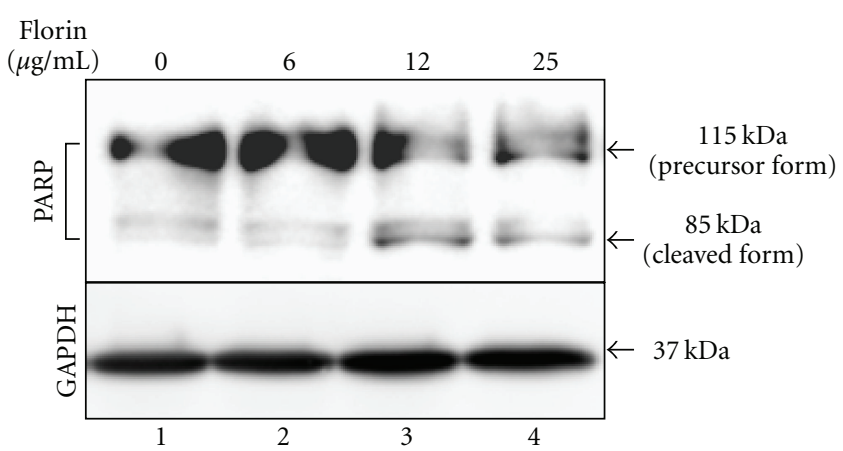

(D)

FIGURE 2: Analysis of the effect of Florin extracts on apoptosis in TCCSUP cells. (A) Cells were treated with 0, 6, 12, or 25 $\mu \mathrm{g} / \mathrm{mL}$ of Florin extracts. After $18 \mathrm{~h}$, the percentage of early apoptotic cells was assessed by Annexin-V/PI binding assay. (B) After $24 \mathrm{~h}$, the adherent cells or suspension cells were collected and subjected to DAPI staining. (C) The ratio of DAPI-stained cells was calculated and the data are presented as mean \pm S.D. ${ }^{*} P<.05$, ${ }^{* *} P<.01$. (D) After the cells were treated with $0,6,12$, and $25 \mu \mathrm{g} / \mathrm{mL}$ of Florin extracts for $48 \mathrm{~h}$, the PARP protein was resolved on $10 \%$ SDS-PAGE and then Western blot was performed. GAPDH was used as a control.

of Florin extracts (Figure 2(B), e and f). The apoptosis index of these treated cells is shown in Figure 2(C). After $48 \mathrm{~h}$ of treatment with $12 \mu \mathrm{g} / \mathrm{mL}$ or $25 \mu \mathrm{g} / \mathrm{mL}$ of Florin extracts, a 85 $\mathrm{kDa}$ proteolytic product of PARP was observed (Figure 2(D), lanes 3 and 4).
3.3. Cell Cycle Arrest at the G2/M Phase. To study the effect of Florin extracts on the different phases of cell cycles, we mainly used TCCSUP cells for the experiments. TCCSUP cells were treated with various concentrations $(6,12$, and $25 \mu \mathrm{g} / \mathrm{mL}$ ) of Florin extracts for $24 \mathrm{~h}$ and then analyzed 
by a fluorescence-activated cell sorter (FACS). The percentage of TCCSUP cells at the G2/M phase markedly increased in a Florin-extracts concentration-dependent manner (Figure 3(a)). The percentages of TCCSUP cells in the $\mathrm{G} 2 / \mathrm{M}$ phase were estimated to be $29.4 \pm 0.3,36.0$ $\pm 2.7,59.4 \pm 0.4$, and $94.6 \pm 1.1 \%$ after treatment of these cells with $0,6,12$, and $25 \mu \mathrm{g} / \mathrm{mL}$ of Florin extracts, respectively (Table 1 ). These results indicate that Florin extracts arrest TCCSUP cells at the G2/M phase. To test the time dependence of the effect, cells were treated with $25 \mu \mathrm{g} / \mathrm{mL}$ of Florin extracts for $6,12,24,36$, and $48 \mathrm{~h}$, and the cell cycle of treated cells were analyzed. As shown in Figure 3(b) and Table 2, the G2/M arrest was observed at $6 \mathrm{~h}(59.6 \pm 2.1 \%)$, reached a maximal level (>90\%) $(94.6$ $\pm 0.1 \%$ ) at $24 \mathrm{~h}$, and then gradually decreased (due to cell death). The sub-G1 cells increased to $15.4 \pm 2.3 \%$ at $48 \mathrm{~h}$. These results suggest that Florin extracts induce G2/M phase arrest in a time-dependent manner.

3.4. Effects of Florin Extracts on Cell Cycle-Related and Apoptotic Proteins. The expression of cyclin B1, Cdc2, and phosphorylated Cdc2 ( $\mathrm{p}-\mathrm{Cdc} 2)$, key regulators of cell entry into mitosis, was monitored by immunoblotting assay. The treatment time points are as indicated in Figure 3(b). As shown in Figure 4(a), the levels of cyclin B1 and Cdc2 kinase were upregulated after a $6 \mathrm{~h}$ treatment of TCCSUP cells with Florin extracts (lane 2). Interestingly, the slow migrating forms of cyclin B1 and $\mathrm{Cdc} 2$ were converted to the fast migrating forms of these molecules after treatment of cells with Florin extracts for 24 and $36 \mathrm{~h}$ (lanes 6 and 8). The slow and fast migrating forms may represent hyperphosphorylated and hypophosphorylated (or dephosphorylated) forms of cyclin B1 and Cdc2, respectively. Cdc25C was upregulated after treatment of the cells with Florin extracts for 6, 12, and $24 \mathrm{~h}$ (Figure 4(a), lanes 2, 4, and 6), then decreased after $36 \mathrm{~h}$ treatment (lane 8), as compared with untreated cells (Figure 4(a), lanes 1, 3 and 5). On the other hand, Florin extracts induced a decrease of P-Cdc2 in a time-dependent manner. Because the Cdc2 level was not significantly altered after treatment of cells with Florin extracts for 12, 24, and $36 \mathrm{~h}$, this suggests that treatment with Florin extracts induces dephosphorylation of P-Cdc2 in a time-dependent manner. This suggestion is supported by the observation that the hypophosphorylated or dephosphorylated form (fast migrating form) of Cdc2 was the major molecule of Cdc 2 in cells treated with Florin extracts for 24 and 48 h (Figure 4(a), lanes 6 and 8). Increase of cyclin B1 levels and Cdc2 dephosphorylation (activation) is known to be associated with mitotic arrest [16, 17]. These results support the suggestion that Florin extracts arrest cells at the G2/M phase of the cell cycle. In this study, we also found that Florinextracts induced phosphorylation (slow migrating form) and degradation of $\mathrm{Bcl}-2$ correlated with the production of the fast migrating form (dephosphorylated form) of Cdc2 (Figure 4(a), lanes 6 and 8). These results may imply that the increase of $\mathrm{Cdc} 2$ kinase activity is associated with degradation or instability of $\mathrm{Bcl}-2$, an antiapoptotic protein. Furthermore, after TCCSUP cells were treated with 12 or
TABLe 1: Flow cytometry analysis in TCCSUP cells treated with Florin extracts.

\begin{tabular}{llccc}
\hline Dose & $\begin{array}{l}\text { Percentage (mean } \pm \text { S.D.) of TCCSUP bladder cancer } \\
\text { cells at each cell cycle phase after treatment with } \\
\text { different concentrations of Florin extracts }(\mu \mathrm{g} / \mathrm{mL}) \text { at } \\
\\
\text { 24h. }\end{array}$ \\
\hline subG1 (\%) & G1 (\%) & S (\%) & G2/M (\%) \\
\hline 0 & $0.8 \pm 0.3$ & $54.6 \pm 0.5$ & $15.2 \pm 0.1$ & $29.4 \pm 0.3$ \\
$($ control) & & $46.6 \pm 2.5$ & $16.0 \pm 1.7$ & $36.0 \pm 2.7^{*}$ \\
6 & $1.4 \pm 0.5$ & $24.9 \pm 1.1$ & $12.8 \pm 0.8$ & $59.4 \pm 0.4^{* *}$ \\
12 & $2.9 \pm 0.1$ & $2.2 \pm 0.2$ & $1.9 \pm 1.3$ & $94.6 \pm 1.1^{* * *}$ \\
\hline 25 & $1.3 \pm 0.2$ &
\end{tabular}

${ }^{a}$ TCCSUP cell growth was arrested at the G2/M phase after Florin-extract treatment in a dose-dependent manner, and these cells were significantly different from the control cells.

${ }^{\mathrm{b}}$ Cell numbers decreased significantly at the G1 phase $\left({ }^{*} P<.05,{ }^{* *} P<.01\right.$, *** $P<.001)$.

$25 \mu \mathrm{g} / \mathrm{mL}$ of Florin extracts for $24 \mathrm{~h}$, the level of Bax, a proapoptotic protein, increased in accompany with the decrease of Bcl-2 levels (Figure 4(b), lanes 3 and 4).

3.5. Florin Extracts Inhibit Tubulin Polymerization in TCCSUP Cells. We next wanted to determine whether the quantitative change in tubulin levels and the altered balance of polymerization and depolymerization account for the effects of Florin extracts. We fractioned the soluble and polymerized tubulin in Florin-extract-treated cells, performed Western blot analysis, and determined the percentage of tubulin polymers to monomers. As shown in Figure 5(a), treatment of cells with Florin extracts for $24 \mathrm{~h}$ dramatically decreased the tubulin levels ( $>90 \%$ ) as compared to control. Treatment with Taxol $(0.1 \mu \mathrm{g} / \mathrm{mL})$, an inhibitor of tubulin depolymerization, profoundly increased the polymerized tubulin (approximately fivefold as compared to control) (Figure 5(b)). We also determined the effects of Florin extracts on the microtubule network in TCCSUP cells by immunofluorescence confocal microscopy (Figure 6). Normal prometaphase microtubule organization in the control cells is shown in Figure 6(a). Treatment with a high concentration of Florin $(25 \mu \mathrm{g} / \mathrm{mL})$ caused a significant reduction of microtubule density in the apoptotic cells (Figure 6(b)). Furthermore, treatment with colchicine $(0.1 \mu \mathrm{g} / \mathrm{mL})$ resulted in inhibition of microtubule polymerization and reduction of microtubule density in the cytoplasm (Figure 6(c)). In contrast, Taxol $(0.1 \mu \mathrm{g} / \mathrm{mL})$ treatment resulted in the formation of microtubule "bundles" (Figure 6(d)). In the experiments, we also determined that the amount of $\beta$ tubulin which represented half of the total amount of polymerized tubulin. (data not shown).

3.6. Effects of Florin Extracts on the Activities of Caspase3, -8, and -9 in TCCSUP Cells. Caspase-3, -8, and -9 play crucial roles in the apoptotic pathway, which contain a mitochondria-related "intrinsic pathway" and death receptor-related "extrinsic pathway" $[18,19]$. To study the effect of time length on caspase-3, -8 , and -9 activities, TCCSUP cells were treated with $25 \mu \mathrm{g} / \mathrm{mL}$ of Florin extracts for 12,24 , and $48 \mathrm{~h}$. The activities of these enzymes in the 

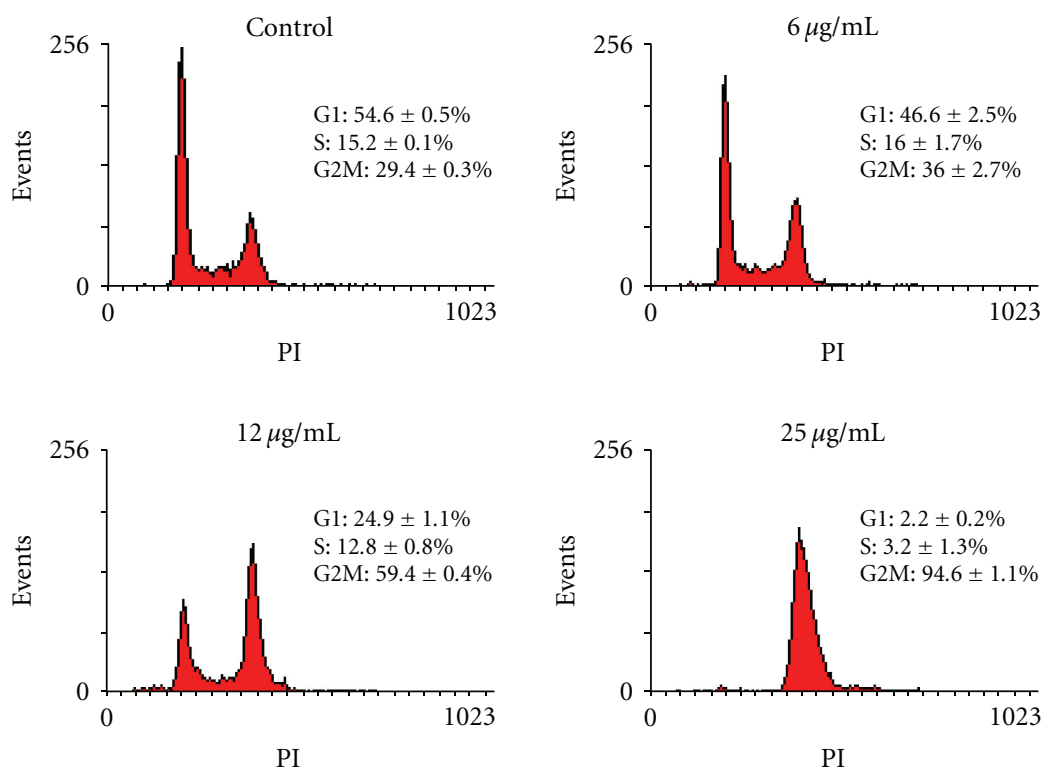

(a)
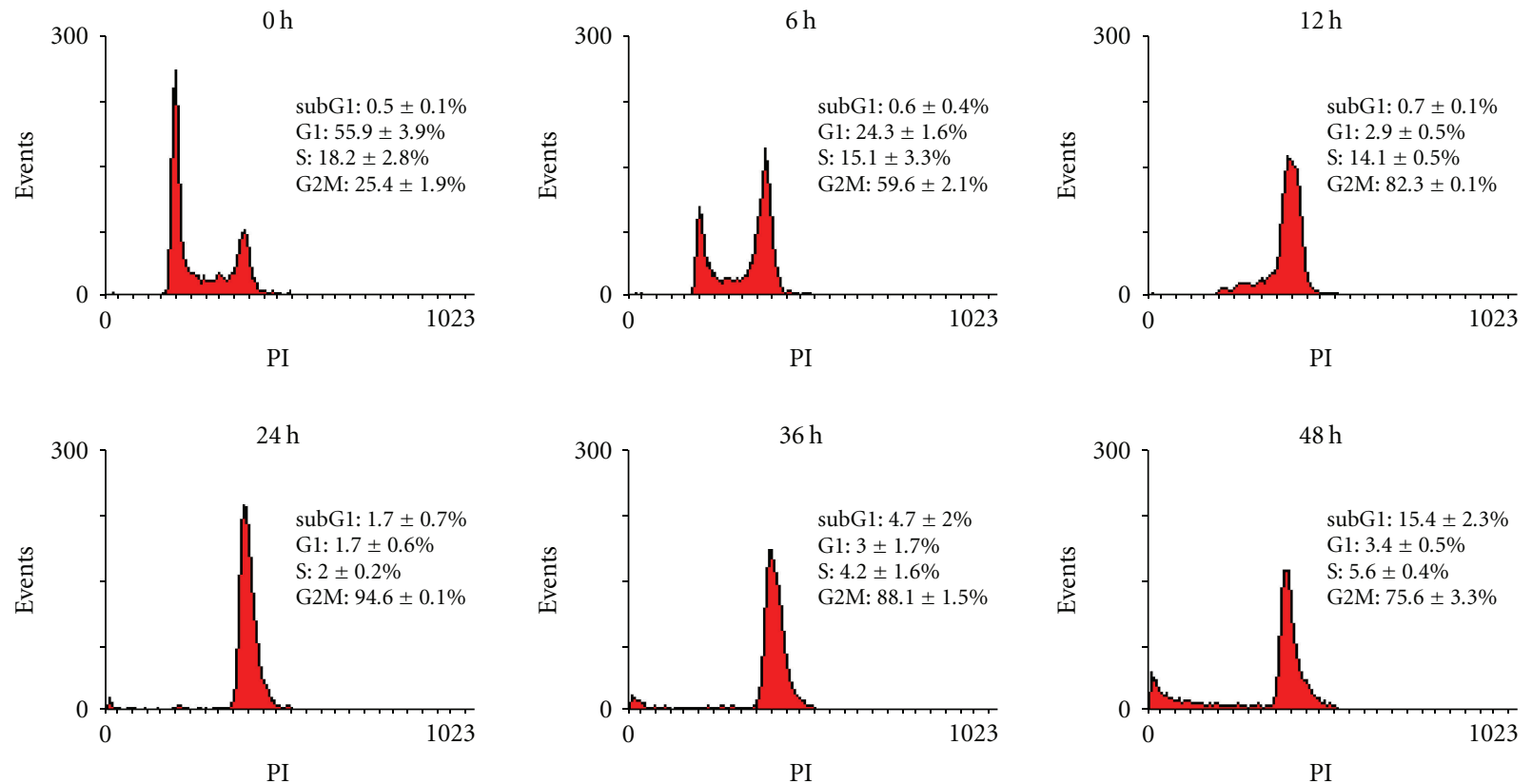

(b)

FIGURE 3: Flow cytometry analysis of TCCSUP cells treated with Florin extracts. (a) Cells were treated with 6,12 , and $25 \mu \mathrm{g} / \mathrm{mL}$ of Florin extract for $24 \mathrm{~h}$. (b) Cells were treated with $25 \mu \mathrm{g} / \mathrm{mL}$ of Florin extracts for $6,12,24,36$, and $48 \mathrm{~h}$ and then stained with PI. Florin extracts induced significant cell cycle arrest at the G2/M phase; however, cell numbers decreased significantly at phase G1 $\left({ }^{*} P<.05\right)$.

treated cells were analyzed. As shown in Figure 7, compared to the control treatment, caspase- 8 and -3 activities were significantly increased after treatment of cells with Florin extracts for 12,24 , and $48 \mathrm{~h}$. For example, the caspase- 9 activity was increased by 1.5 -fold after $24 \mathrm{~h}$, as compared to the control treatment.

\section{Discussion}

In the current study, we have demonstrated that Florin extracts inhibited cell proliferation (Figure 1), and arrested the cell growth at the G2/M phase (Figure 3). Florin extracts appeared to have a potent selectivity toward 4 bladder cancer cells $\left(\mathrm{IC}_{50} \mathrm{~s}=\sim 9-17 \mu \mathrm{g} / \mathrm{mL}\right.$ versus $\mathrm{IC}_{50}=\sim 27 \mu \mathrm{g} / \mathrm{mL}$ in SV40-immortalized normal uroepithelial cells). Presently, Florin extracts used is very crude; its antibladder cancer cell activity with $\mathrm{IC}_{50} \mathrm{~s}$ of $9-17 \mu \mathrm{g} / \mathrm{mL}$ is relatively potent. However, it is possible that the blood or tissue concentrations of Florin extracts active components may not be able to reach the $\mathrm{IC}_{50} \mathrm{~s}$. To address this potential problem, one could increase the dosage of Florin extracts to a few hundred $\mathrm{mg} / \mathrm{kg}$. However, the potential side or toxicity effects of 


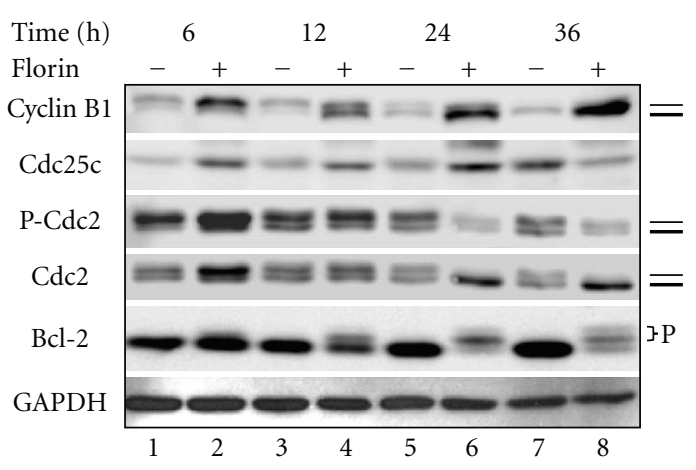

(a)

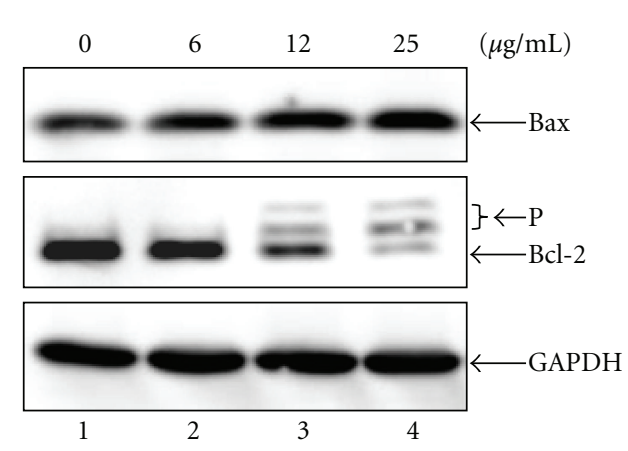

(b)

FIGURE 4: Western blot analysis of cell cycle regulatory protein levels and apoptosis proteins in TCCSUP cells treated with Florin extracts. (a) Cdc25C, Cdc-2, pCdc-2, cyclin-B1, and Bcl-2 proteins were analyzed after cells were exposed to Florin extracts. Cells were treated with $25 \mu \mathrm{g} / \mathrm{mL}$ of Florin extracts for 6, 12, 24, and $36 \mathrm{~h}$. Proteins $(50 \mu \mathrm{g})$ from each sample was resolved on 12\% SDS-PAGE and Western blot was performed. GAPDH was used as a control. The thick and thin bars indicate the locations of the fast (dephosphorylated) and slow (phosphorylated) migrating forms of cyclin B1, P-Cdc2, or Cdc2, respectively. (b) Expression of Bcl-2 and Bax proteins in TCCSUP cells was analyzed. Cells were treated with 6,12 , and $25 \mu \mathrm{g} / \mathrm{mL}$ of Florin extracts for $24 \mathrm{~h}$. Proteins $(50 \mu \mathrm{g})$ from each sample were resolved on $12 \%$ SDS-PAGE and Western blot was performed. GAPDH was used as a control. The two slow migrating forms of Bcl 2 may be the hyperphosphorylated forms of $\mathrm{Bcl} 2$.

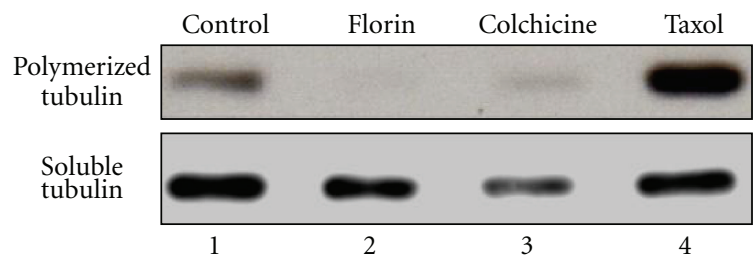

(a)

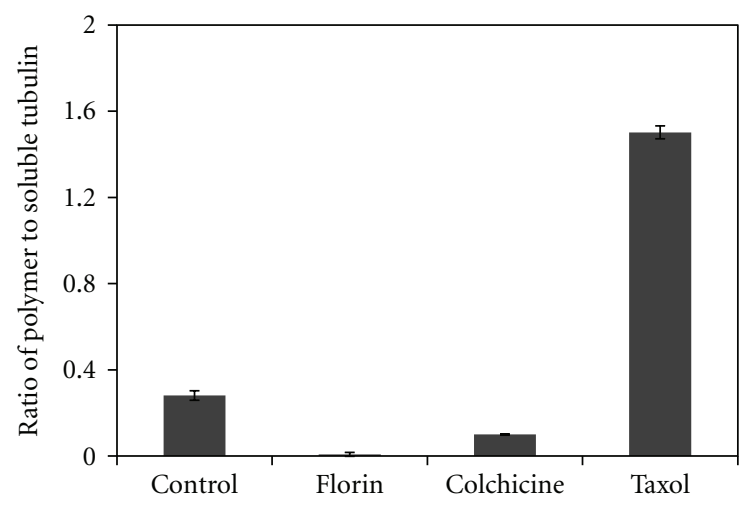

(b)

FIGURE 5: Determination of the percentages of polymerized to soluble $\beta$-tubulin in TCCSUP cells treated with Florin extracts. Cells (2 $\left.\times 10^{6}\right)$ were pre-cultured for $24 \mathrm{~h}$ and treated with Florin extracts $(25 \mu \mathrm{g} / \mathrm{mL})$, colchicine $(0.05 \mu \mathrm{g} / \mathrm{mL})$, or Taxol $(0.1 \mu \mathrm{g} / \mathrm{mL})$ for $24 \mathrm{~h}$. Treated cells were harvested, lyzed, and soluble and polymerized fractions of tubulin were obtained. About $25 \mu \mathrm{g}$ of soluble and polymerized fraction proteins were used in the Western blot analysis, with antirabbit $\beta$-tubulin monoclonal antibody as a primary antibody. Images were photographed (a), and the percentages of polymerized to soluble tubulin were calculated using the band area (b).

this high dose of Florin extracts have to be addressed. Alternatively, the active components in the Florin extracts could be further concentrated or purified by conventional chromatographic techniques using antibladder cancer cell activity assay. Further studies may also be required to identify the active components responsible for the observed antitumor effect of Florin extracts.

Upregulation of cyclin B1/Cdc2 kinase activity is known to be involved in the G2/M phase transition of the cell cycle $[20,21]$. Cyclin B1 and Cdc2 kinase regulate the entry and progression of the mitotic phase in eukaryotic cells. A previous report showed that the activation of Cdc2 kinase at the $\mathrm{G} 2 / \mathrm{M}$ transition requires accumulation of cyclin B1 and Cdc2 $[17,21]$. Cdc2 kinase is activated by the specific phosphatase Cdc25C $[22,23]$. Here we demonstrate that treatment of bladder cancer cells with Florin extracts results in an increase of cyclin B1/Cdc2 kinase activity as evidenced by increased levels of dephosphorylated Cdc2 kinase (activated Cdc2 kinase) in cells treated with Florin extracts. The microtubule network plays an important role in the regulation of mitotic apparatus. Cells are arrested in the $\mathrm{M}$ phase when microtubule dynamics are disrupted. Our data shows that treatment with Florin extracts induces depolymerization of microtubules in bladder cancer cells. This occurs by decreasing $\beta$-tubulin expression in these cells. Microtubules are composed of $\alpha$-tubulin and $\beta$-tubulin. Several reports have indicated that both the microtubule-stabilizing agents (such as Taxol) and the microtubule-depolymerizing agents (such as Vinblastine and colchicine) [24-26] exhibit potent anticancer activity by inhibiting cell cycle progression and 


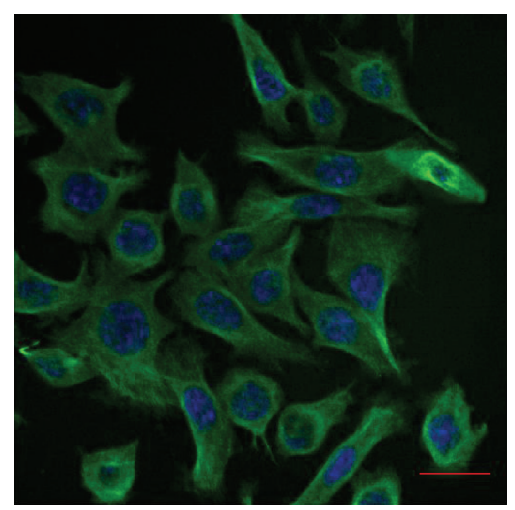

(a)

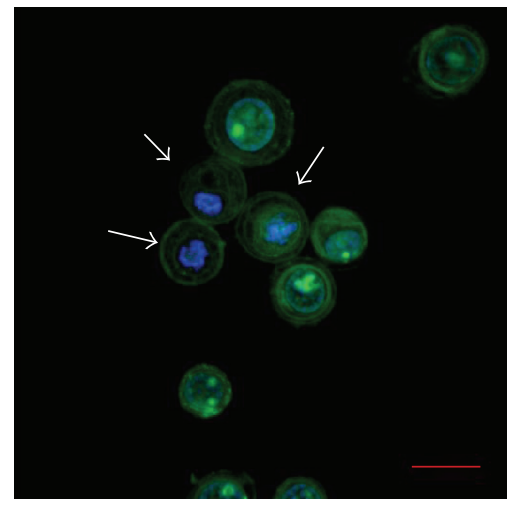

(c)

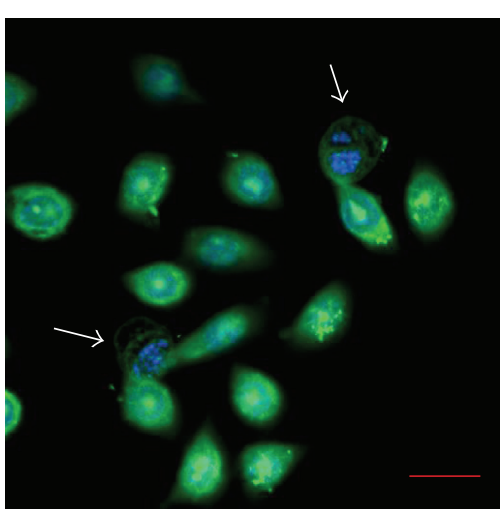

(b)

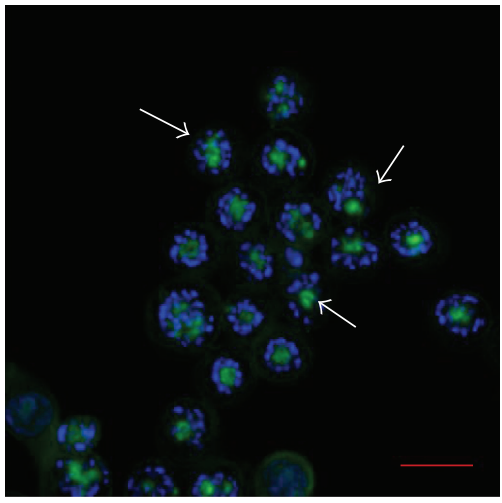

(d)

FIGURE 6: Effect of treatment with Florin extracts on the amount of prometaphase microtubules in TCCSUP cells. (a) Cells were incubated with vehicle $(0.1 \%$ dimethylsulfoxide) for $24 \mathrm{~h}$. (b) Cells were treated with $25 \mu \mathrm{g} / \mathrm{mL}$ of Florin extracts, (c) $0.1 \mu \mathrm{g} / \mathrm{mL}$ of colchicine, or (d) $0.1 \mu \mathrm{g} / \mathrm{mL}$ Taxol for $24 \mathrm{~h}$. Control indicates vehicle-treated cells. Microtubules (green) and nuclei (blue) are shown. Scale bar, $20 \mu \mathrm{m}$. Some of the $\beta$-tubulin are indicated by white arrows in (b), (c), and (d). (630x original magnification).

TABLE 2: Flow cytometry analysis in TCCSUP cells treated with Florin extracts.

Percentage (mean \pm S.D.) of TCCSUP bladder cancer

Time (h) cells at each cell cycle phase after treatment with Florin extract $(25 \mu \mathrm{g} / \mathrm{mL})$ at different time points

\begin{tabular}{lcccl}
\hline & subG1 $(\%)$ & G1 $(\%)$ & S $(\%)$ & G2M $(\%)$ \\
\hline 0 & $0.5 \pm 0.1$ & $55.9 \pm 3.9$ & $18.2 \pm 2.8$ & $25.4 \pm 1.9$ \\
6 & $0.6 \pm 0.4$ & $24.3 \pm 1.6$ & $15.1 \pm 3.3$ & $59.6 \pm 2.1^{* *}$ \\
12 & $0.7 \pm 0.1$ & $2.9 \pm 0.5$ & $14.1 \pm 0.5$ & $82.3 \pm 0.1^{* * *}$ \\
24 & $1.7 \pm 0.7$ & $1.7 \pm 0.6$ & $2.0 \pm 0.2$ & $94.6 \pm 0.1^{* * *}$ \\
36 & $4.7 \pm 2.0$ & $3.0 \pm 1.7$ & $4.2 \pm 1.6$ & $88.1 \pm 1.5^{* * *}$ \\
48 & $15.4 \pm 2.3$ & $3.4 \pm 0.5$ & $5.6 \pm 0.4$ & $75.6 \pm 3.3^{* * *}$ \\
\hline
\end{tabular}

${ }^{a}$ TCCSUP cell growth was arrested at the G2/M phase after Florin-extracts treatment in a time-dependent manner, and these cells were significantly different from those at baseline (0).

${ }^{\mathrm{b}}$ There was a significant difference between these cells and those in the control group $(* * P<.01, * * * P<.001)$.

inducing cell apoptosis [26, 27]. Thus, we used colchicine and Taxol as controls. The experimental results reveal that treatment of bladder cancer cells with Florin extracts leads to cell cycle arrest at the G2/M phase. This appears to be mediated, at least in part, by depolymerizing microtubules as colchicine does.

Anti-microtubule agents, including Taxol, Doxetaxel, Vincristine, and colchicine, have been shown to induce cell growth arrest, phosphorylation of Bcl-2, increased Bax protein levels, and finally cell death. This involves the mitochondrial pathway and activation of caspase- 9 and caspase3 [28-30]. Bcl-2 is known to play an important role in the intrinsic apoptosis pathway and protects the microtubule integrity [18]. Here we demonstrated that treatment with Florin extracts induce apoptosis in bladder cancer cells, as determined by Annexin- $\mathrm{V}$ assay and caspase- $3,-8$, and 9 activity measurement. The apoptotic activity of Florin extracts in bladder cancer cells appears to be mediated by (1) increase of cyclin B1/Cdc2 kinase activity, (2) inhibition of tubulin polymerization, (3) phosphorylation and degradation of $\mathrm{Bcl}-2$, an antiapoptotic protein, and (4) increased production of Bax, an apoptotic protein.

The death receptor-signaling cascade belongs to the extrinsic pathway [19] which involves activation of caspase-8. Our study shows that TCCSUP cells treated with Florin for $12 \mathrm{~h}$ exhibit up-regulation of both initiator caspase (caspase8 and -9) and effector caspase (caspase-3) and that caspase- 8 is upregulated earlier than caspase- 9 and caspase- 3 in these 


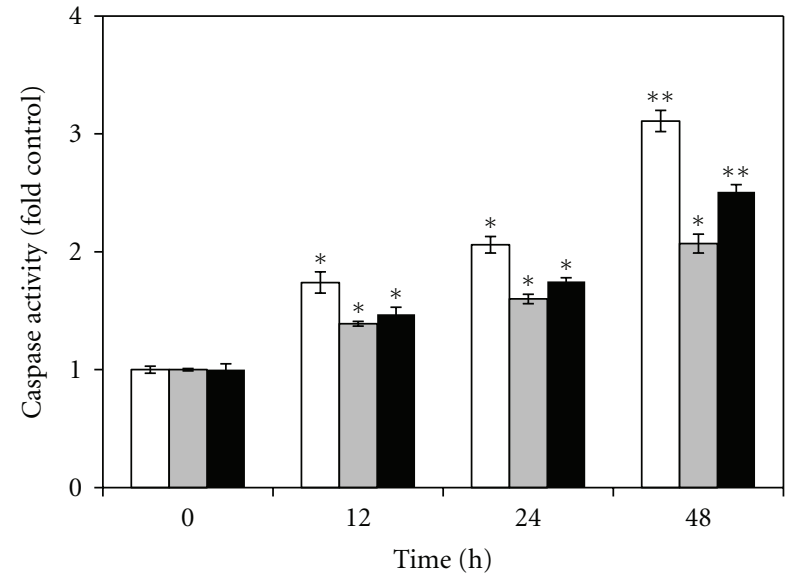

$\square$ Caspase-8
$\square$ Caspase-9
$\square$ Caspase-3

Figure 7: Effects of Florin extracts on caspase-3, -8, and -9 activities in TCCSUP cells. After treatment with $25 \mu \mathrm{g} / \mathrm{mL}$ of Florin extracts for 12,24 , and $48 \mathrm{~h}$, cell lysates were prepared and enzymatic activities of caspase- $3,-8$, and -9 were measured by colorimetric assay. The caspase- $3,-8$, and -9 activities in control cells were taken as 1 -fold, and the relative changes of these activities in the treated cells were estimated $\left({ }^{*} P<.05,{ }^{*} P<.01\right)$.

cells treated with Florin extracts. Caspase-3, which cleaves PARP protein, plays an important role in the execution of apoptosis. Elevated levels of caspase-3 (up to 2.5-fold of control) are observed after $48 \mathrm{~h}$ of Florin-extract treatment. Therefore, our results suggest that apoptosis of Florin extract-treated TCCSUP cells occurs through the arrest of the cell cycle at the G2/M phase and then proceeds through both the death receptor and the mitochondrial pathways.

\section{Acknowledgments}

This study was supported by a grant from Taichung Veterans General Hospital (TCVGH-995001B), Taichung, Taiwan. C.L. Cheng and C.-R. Yang contributed equally to this paper.

\section{References}

[1] D. Dhawan, A. B. Jeffreys, R. Zheng, J. C. Stewart, and D. W. Knapp, "Cyclooxygenase-2 dependent and independent antitumor effects induced by celecoxib in urinary bladder cancer cells," Molecular Cancer Therapeutics, vol. 7, no. 4, pp. 897904, 2008.

[2] C. C. Peng, K. C. Chen, R. Y. Peng, C. H. Su, and H. M. Hsieh$\mathrm{Li}$, "Human urinary bladder cancer T24 cells are susceptible to the Antrodia camphorata extracts," Cancer Letters, vol. 243, no. 1, pp. 109-119, 2006.

[3] K. Shimada, M. Nakamura, M. A. De Velasco et al., "Role of syndecan-1 (CD138) in cell survival of human urothelial carcinoma," Cancer Science, vol. 101, no. 1, pp. 155-160, 2010.

[4] C. Wilasrusmee, J. Siddiqui, D. Bruch, S. Wilasrusmee, S. Kittur, and D. S. Kittur, "In vitro immunomodulatory effects of herbal products," American Surgeon, vol. 68, no. 10, pp. 860-864, 2002.
[5] W. J. Craig, "Health-promoting properties of common herbs," American Journal of Clinical Nutrition, vol. 70, no. 3, pp. 491S499S, 1999.

[6] D. J. Newman, G. M. Cragg, and K. M. Snader, "Natural products as sources of new drugs over the period 1981-2002," Journal of Natural Products, vol. 66, no. 7, pp. 1022-1037, 2003.

[7] G. M. Cragg and D. J. Newman, "Plants as a source of anticancer agents," Journal of Ethnopharmacology, vol. 100, no. 12, pp. 72-79, 2005.

[8] T. B. Yen, H. T. Chang, C. C. Hsieh, and S. T. Chang, "Antifungal properties of ethanolic extract and its active compounds from Calocedrus macrolepis var. formosana (Florin) heartwood," Bioresource Technology, vol. 99, no. 11, pp. 4871-4877, 2008.

[9] L. K. Chao, K. F. Hua, H. Y. Hsu, Y. C. Su, and S. T. Chang, "Bioactivity assay of extracts from Calocedrus macrolepis var. formosana bark," Bioresource Technology, vol. 97, no. 18, pp. 2462-2465, 2006.

[10] K. P. Chao, K. F. Hua, H. Y. Hsu, Y. C. Su, and S. T. Chang, "Anti-inflammatory activity of sugiol, a diterpene isolated from Calocedrus formosana bark," Planta Medica, vol. 71, no. 4, pp. 300-305, 2005.

[11] C. C. Tsai, C. J. Chen, H. W. Tseng et al., "Cytomic screening of immuno-modulating activity compounds from Calocedrus formosana," Combinatorial Chemistry and High Throughput Screening, vol. 11, no. 10, pp. 834-842, 2008.

[12] S. S. Cheng, H. T. Chang, C. L. Wu, and S. T. Chang, "Antitermitic activities of essential oils from coniferous trees against Coptotermes formosanus," Bioresource Technology, vol. 98, no. 2, pp. 456-459, 2007.

[13] C. L. Hsieh, M. H. Tseng, Y. Y. Shao et al., "C terpenoids from the bark of Calocedrus macrolepis var. formosana with activity against human cancer cell lines," Journal of Natural Products, vol. 69, no. 11, pp. 1611-1613, 2006.

[14] D. J. Stravopodis, P. K. Karkoulis, E. G. Konstantakou et al., "Thymidylate synthase inhibition induces p53-dependent and p53-independent apoptotic responses in human urinary bladder cancer cells," Journal of Cancer Research and Clinical Oncology, vol. 137, pp. 359-374, 2011.

[15] C. C. Peng, K. C. Chen, R. Y. Peng, C. C. Chyau, C. H. Su, and H. M. Hsieh-Li, "Antrodia camphorata extract induces replicative senescence in superficial TCC, and inhibits the absolute migration capability in invasive bladder carcinoma cells," Journal of Ethnopharmacology, vol. 109, no. 1, pp. 93103, 2007.

[16] S. Kim, H. S. Lee, S. K. Lee et al., "12-O-Tetradecanoyl phorbol-13-acetate (TPA)-induced growth arrest is increased by silibinin by the down-regulation of cyclin B1 and cdc2 and the up-regulation of p21 expression in MDA-MB231 human breast cancer cells," Phytomedicine, vol. 17, pp. 1127-1132, 2010.

[17] J. M. Mulligan, L. M. Greene, S. Cloonan et al., "Identification of tubulin as the molecular target of proapoptotic pyrrolo-1,5benzoxazepines," Molecular Pharmacology, vol. 70, no. 1, pp. 60-70, 2006.

[18] S. Haldar, A. Basu, and C. M. Croce, "Bcl2 is the guardian of microtubule integrity," Cancer Research, vol. 57, no. 2, pp. 229-233, 1997.

[19] J. E. Chipuk and D. R. Green, "Do inducers of apoptosis trigger caspase-independent cell death?" Nature Reviews Molecular Cell Biology, vol. 6, no. 3, pp. 268-275, 2005.

[20] C. Norbury and P. Nurse, "Animal cell cycles and their control," Annual Review of Biochemistry, vol. 61, pp. 441-470, 1992. 
[21] B. C. Dash and W. S. El-Deiry, "Phosphorylation of p21 in G/M promotes cyclin B-Cdc2 kinase activity," Molecular and Cellular Biology, vol. 25, no. 8, pp. 3364-3387, 2005.

[22] A. Kumagai and W. G. Dunphy, "The cdc25 protein controls tyrosine dephosphorylation of the cdc2 protein in a cell-free system," Cell, vol. 64, no. 5, pp. 903-914, 1991.

[23] K. L. King and J. A. Cidlowski, "Cell cycle and apoptosis: common pathways to life and death," Journal of Cellular Biochemistry, vol. 58, no. 2, pp. 175-180, 1995.

[24] P. M. Checchi, J. H. Nettles, J. Zhou, J. P. Snyder, and H. C. Joshi, "Microtubule-interacting drugs for cancer treatment," Trends in Pharmacological Sciences, vol. 24, no. 7, pp. 361-365, 2003.

[25] S. Honore, E. Pasquier, and D. Braguer, "Understanding microtubule dynamics for improved cancer therapy," Cellular and Molecular Life Sciences, vol. 62, no. 24, pp. 3039-3056, 2005.

[26] W. Li, M. S. Lam, A. Birkeland et al., "Cell-based assays for profiling activity and safety properties of cancer drugs," Journal of Pharmacological and Toxicological Methods, vol. 54, no. 3, pp. 313-319, 2006.

[27] S. Y. Yuan, S. L. Hsu, K. J. Tsai, and C. R. Yang, "Involvement of mitochondrial pathway in Taxol-induced apoptosis of human T24 bladder cancer cells," Urological Research, vol. 30, no. 5, pp. 282-288, 2002.

[28] Y. H. Kuo, C. H. Chen, S. C. Chien, and H. C. Lin, "Novel diterpenes from the heartwood of Chamaecyparis obtusa var. formosana," Chemical and Pharmaceutical Bulletin, vol. 52, no. 6, pp. 764-766, 2004.

[29] J. P. Liou, C. Y. Wu, H. P. Hsieh et al., "4- And 5-aroylindoles as novel classes of potent antitubulin agents," Journal of Medicinal Chemistry, vol. 50, no. 18, pp. 4548-4552, 2007.

[30] I. Vitale, A. Antoccia, C. Cenciarelli et al., "Combretastatin CA-4 and combretastatin derivative induce mitotic catastrophe dependent on spindle checkpoint and caspase-3 activation in non-small cell lung cancer cells," Apoptosis, vol. 12, no. 1, pp. 155-166, 2007. 


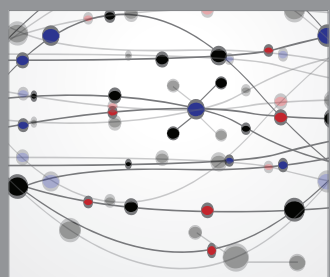

The Scientific World Journal
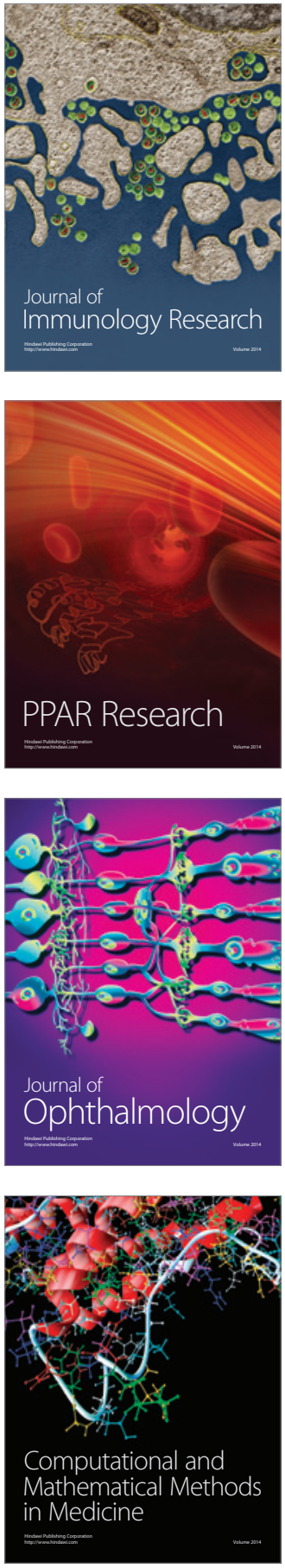

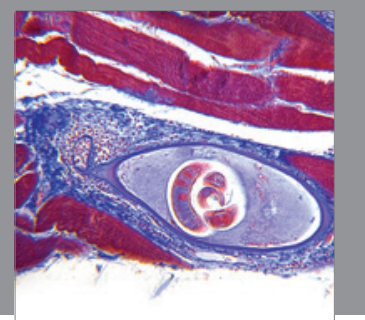

Gastroenterology

Research and Practice
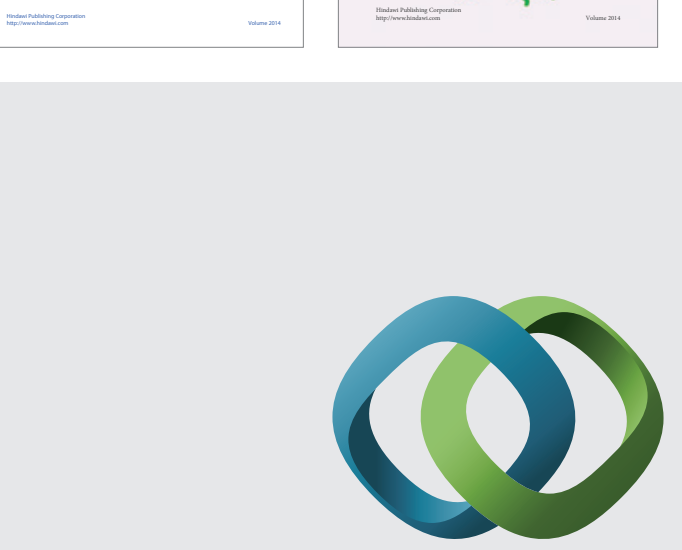

\section{Hindawi}

Submit your manuscripts at

http://www.hindawi.com
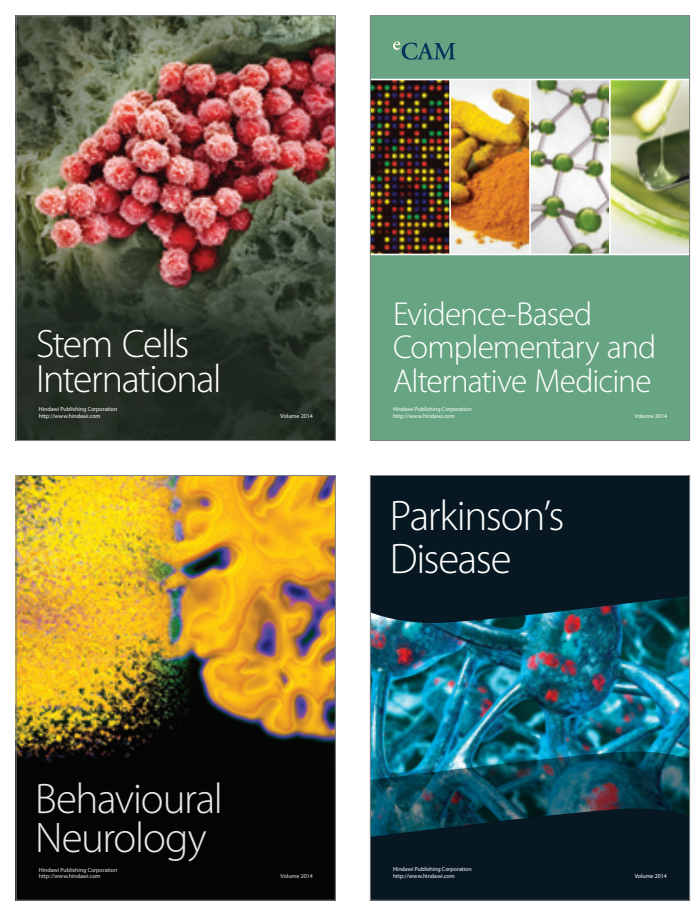

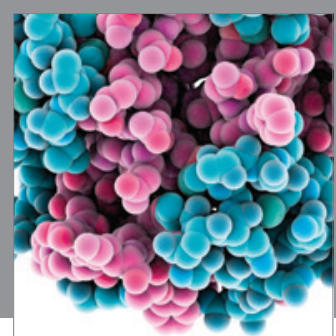

Journal of
Diabetes Research

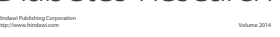

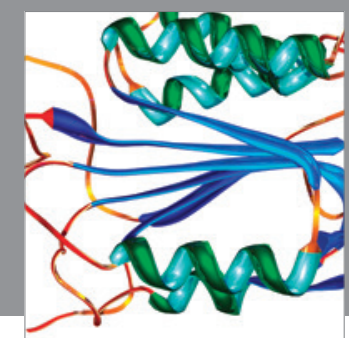

Disease Markers
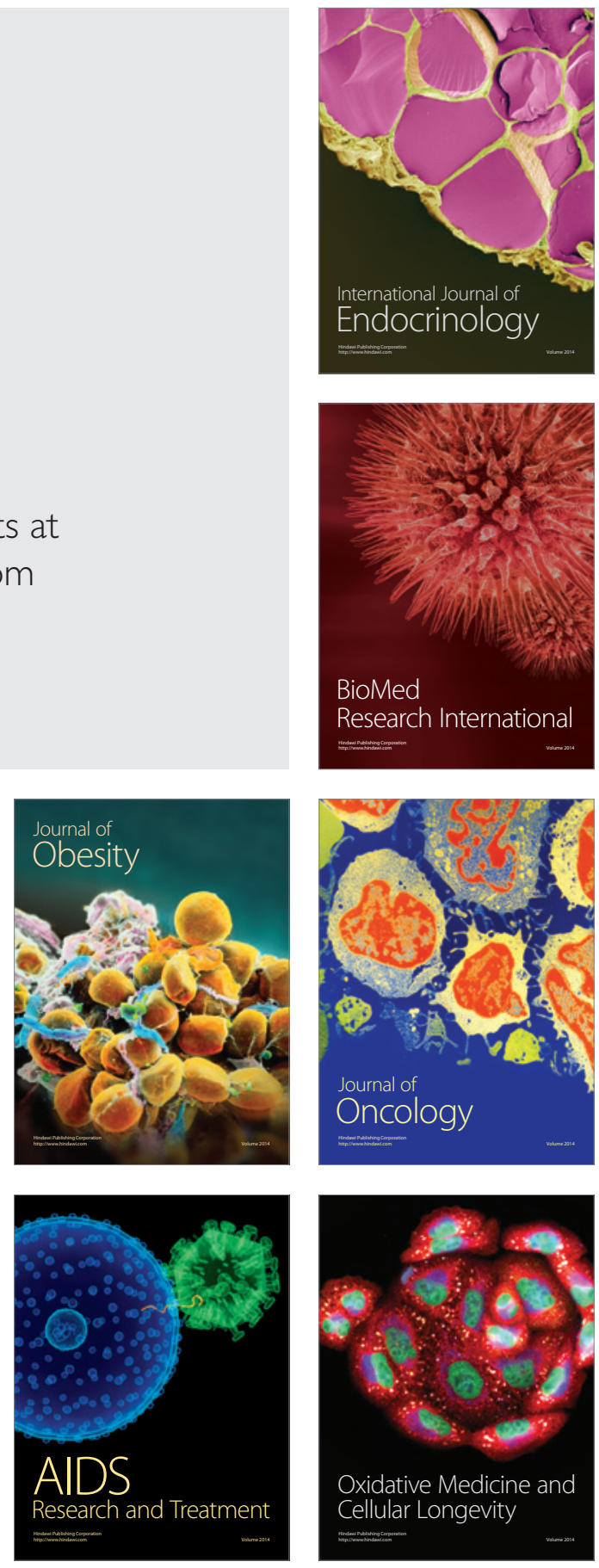